\title{
Muse 細胞による新規脳梗塞治療法の開発
}

新妻邦泰 ${ }^{*}$, 冨永悌二 2

\section{Development of muse cell therapy for ischemic stroke}

Kuniyasu NIIZUMA, Teiji TOMINAGA

要約：脳梗塞とは，脳を栄養する血管が閉塞もしくは狭窄することにより，その灌流領域に血流不全が生じ十 分な酸素や栄養が供給されなくなり, 結果として脳神経細胞が傷害されてしまう疾患である. 近年の血栓溶解 薬やカテーテル治療の進歩により脳梗塞の転帰は改善してきているものの, 未だそれらの再開通療法の適応と なる患者は $10 \%$ 未満であり，大半の患者には脳梗塞が完成することになる．脳は脆弱な組織であり， かつ再生 能力が限定的であることから, 完成した脳梗塞に対する根本的な治療は存在しなかったが, 近年では幹細胞治 療により脳を再生させられる可能性が見いだされ期待が集まっている. 本稿では脳梗塞に対する幹細胞治療の 現状を概説後, Muse 細胞を用いた新規治療開発につき述べる.

Key words: infarction, ischemic stroke, muse cell, regeneration, stem cell

\section{1.はじめに}

脳梗塞とは，脳を栄養する血管の閉塞もしくは狭 窄することにより，その灌流領域に血流不全が生じ 十分な酸素や栄養が供給されなくなり, 結果として 脳神経細胞が傷害されてしまう疾患である。脳は体 重の $2 \%$ 程度の質量でしかないにも関わらず，全身 の酸素の $15 \%$ ，グルコースの $20 \%$ 程度を消費する， 大量のエネルギーを必要とする臓器であるため, ひ とたび血流不全に陥ると, 脳は速やかに傷害されて しまうことが問題となる，脳の血流を阻害する血栓 を薬剤で溶解させる血栓溶解療法や, カテーテルを 用いて機械的に血栓を除去する血栓回収療法といっ た, 脳が障害される前に閉塞血管を再開通させる「再 開通療法」の発達により治療成績は劇的に向上した が, 前述のように脳が傷害されるまでの時間が短い ため, 再開通療法の適応になる患者数は全体の $10 \%$

\footnotetext{
1 東北大学大学院医工学研究科神経外科先端治療開発学分野

2 東北大学大学院医学系研究科神経外科学分野

*責任者連絡先 :

東北大学大学院医工学研究科神経外科先端治療開発学分野

干 980-8575 宮城県仙台市青葉区星陵町 2-1

Tel: 022-717-7230, Fax: 022-717-7233

E-mail: niizuma@nsg.med.tohoku.ac.jp
}

程度にすぎず，90\%の患者では脳梗塞が完成してし まうことになる。

脳は血流不全に脆弱なだけではなく, 再生能力が 限られていることも問題である.1906年にノーベル 賞を受賞した Cajal 博士が著書の中で「Once the development was ended, the founts of growth and regeneration of the axons and dendrites dried up irrevocably. In the adult centers, the nerve paths are something fixed, ended, and immutable. Everything may die, nothing may be regenerated. It is for the science of the future to change, if possible, this harsh decree. $\rfloor^{1)}$ と 述べており,「脳は再生しない」ということが, いわ ば常識として扱われてきた。 その後時を経て, 脳梗 塞をはじめとする種々の傷害後に脳室下帯や海馬の 歯状回を中心として内因性の神経再生が見られるこ とが明らかになったが2,3), 単純な内因性の再生だけ では, 残念ながら十分な機能回復には至らない. 脳 梗塞が完成するとリハビリテーション以外には有効 な治療がないため, 結果として, 約半数の脳梗塞患 者に何らかの障害が後遺し, 大きな社会的な問題と なっている，そのような現状の中で, 脳梗塞により 失われた神経細胞を再生させ得る幹細胞治療・神経 再生療法に大きな期待が集まっている. 


\section{2. 脳梗塞に対する幹細胞治療臨床試験の現状}

脳梗塞に対する幹細胞治療に当初期待されていた ことは，失われた組織を直接的に幹細胞で置換して 修復することであった，しかしながら，様々な前臨 床研究の結果から, 幹細胞治療による脳梗塞の治療 効果のメカニズムは, 抗炎症効果, グリア㓔痕形成 の抑制, オートファジーの促進や栄養因子やサイト カインによる保護効果など, 間接的な効果が主体で あると考えられている ${ }^{4-6)}$.

ヒト脳梗塞に対する幹細胞治療として, 2005 年に 報告された 3 つの報告 ${ }^{7-9)}$ を皮切りに現在に至るま で多数の臨床試験が行われてきた，先駆的であった 3 つの臨床試験に敬意を表し, 概略を示す。 Kondziolka らは, 基底核病変に対して, ヒト teratocarcinoma cell 起源とした LBS-neurons (Layton BioScience, Inc.) を脳内に局所投与する第 2 相試験を 報告した ${ }^{7)}$. 結果として, 統計学的に有意な機能回 復は見られなかったが, LBS-neuronsによる治療の 安全性は証明された，とされている。ただし，けい れんや失神, 硬膜下血腫等の合併症が 18 例中 3 例に 生じていることには注意を要する. Savitzらは, ブ 夕胎児線条体由来の LGE 細胞 (Genvec, Inc.) を脳内 に局所投与する臨床試験を行ったが ${ }^{8)}, 5$ 名の被検 者のうち 2 名に言語機能や運動機能の改善を認めた ものの, 2 名に運動機能の悪化や㽷攣等の有害事象 を認め, 臨床試験が中止となった。また, Bangらは 重症の中大脳動脈領域の脳梗塞に対して自家間葉系 幹細胞を静脈内投与した ${ }^{9)}$. 特に有害事象は生じな かったが, 有意な機能改善も得られなかった.

その後, 様々な臨床試験が行われたが, 用いられ た細胞種, 投与量や投与経路, 投与時期など様々で あり, 一概に論じることはできないが, 幹細胞治療 の安全性は受け入れられるレベルであり, 治療効果 がみられている試験もある. 正確な評価のためには 二重盲検プラセボ対照ランダム化比較試験が必要で あると考えられるが, それが難しい場合でも, 少な くとも評価者は盲検である必要があると思われる. 渉猟しえた限りでは7つの盲検ランダム化あるいは それに近い形のプラセボ対照ランダム化試験が報告 されていた ${ }^{10-16)}$ (表 1).7つの試験の概要を表 1 に
示したが, modified Rankin Scale (mRS) の有意な改 善を伴う機能改善を認めた試験は2つで（Hessらの 試験では 3 ケ月後には有効性を示せなかったが 1 年 後のフォローアップでは mRSや, それを含めた複合 的指標での改善を認めた), その他の機能的指標を含 めてプラセボ群と比較して細胞治療群で改善が認め られた試験は 4つであった. 半分程度のランダム化 比較試験で有意な機能改善が認められているため, 対象や治療プロトコールの最適化により, 更なる治 療成績向上も期待できると思われる。治療時期と細 胞投与経路については, 血液脳関門の破綻や炎症反 応などが大きい急性期であれば静脈内投与を選択す るが, 炎症などが弱くなり, かつ㓔痕組織形成も進 んでいる慢性期であれば，細胞を局所に直接投与す るほうが良いという意見が多いようである。

\section{3. 本邦で進行中の脳梗塞に対する幹細胞治療 (表 2)}

条件付き早期承認制度も手伝い, 本邦は世界有数 の再生医療先進国となりつつある. 現在でも, 筆者 が知る限り5つの幹細胞治療の治験／臨床試験が進 行中である（表 2)，アテローム血栓性梗塞を対象と した札幌医科大学の自家骨髄間葉系幹細胞による治 験, 北海道大学で行われている, 発症後 74 日以内に 自家骨髄間質細胞を脳内に局所投与する RAINBBOW 研究, Healios 社の他家間葉系幹細胞 MultiStem を発症後 18〜36 時間に静注する多施設共 同治験, 帝人株式会社/JCR の歯髄幹細胞 JTR-161を 発症後 48 時間以内に静注する多施設共同治験, そし て我々東北大学が行っている, 生命科学インスティ テュート社の他家 Muse 細胞製品 CL2020を発症後 14〜28 日に静脈内投与する治験である. これらの研 究の結果が明らかになり, 細胞治療が発展すること を期待したい.

\section{Muse 細胞の特徵}

幹細胞治療には様々な細胞が用いられている. 骨 髄単核球細胞, 骨髄間質細胞, 間葉系幹細胞, 歯髄 幹細胞, 脂肪幹細胞, 臍带血幹細胞, 神経幹細胞, 
表 1 脳梗塞に対する幹細胞治療（一重／二重盲検ランダム化試験もしくはPROBE 法を用いた試験のみ）

\begin{tabular}{|c|c|c|c|c|c|c|c|}
\hline 著者 & 発表年 & $\begin{array}{l}\text { 治療群／ } \\
\text { 対照群 (人) }\end{array}$ & $\begin{array}{l}\text { 投与 } \\
\text { 経路 }\end{array}$ & 細胞種 & 細胞数 & 治療時期 & 結果 \\
\hline Chen et al..$^{10)}$ & 2014 & $15 / 15$ & 脳内 & 自家 CD34 陽性造血幹細胞 & $3 \sim 8 \times 10^{6}$ & 6 ケ月～ 5 年 & $\begin{array}{l}\text { 安全性に問題なし. } \\
\mathrm{mRS} \text { を含む複数指標で有意な機能改善. }\end{array}$ \\
\hline Prasad et al. ${ }^{11)}$ & 2014 & $60 / 60$ & 静注 & 自家骨髄単核球細胞 & $\begin{array}{l}2.8 \times 10^{8} \\
\text { (平均值) }\end{array}$ & $7 \sim 30$ 日 & $\begin{array}{l}\text { 安全性に問題なし. } \\
\text { 有意な機能改善なし. }\end{array}$ \\
\hline Hess et al. ${ }^{12}$ & 2017 & $65 / 61$ & 静注 & $\begin{array}{l}\text { 他家骨䯣由来細胞 } \\
\text { (Multistem) }\end{array}$ & $\begin{array}{l}4 \times 10^{6} \\
\text { もしくは } \\
1.2 \times 10^{7}\end{array}$ & $24 \sim 48$ 時間 & $\begin{array}{l}\text { 安全性に問題なし. } \\
90 \text { 日の主要評価項目では差がなかったが, } \\
1 \text { 年の経過観察では有意な mRS 等の改善. }\end{array}$ \\
\hline Bhatia et al. ${ }^{13)}$ & 2018 & $10 / 10$ & 動注 & 自家骨髄単核球細胞 & $\begin{array}{l}6.1 \times 10^{8} \\
\text { (平均值) }\end{array}$ & $8 \sim 15$ 日 & $\begin{array}{l}\text { 安全性に問題なし. } \\
\text { 有意な機能改善なし（細胞治療で改善の傾 } \\
\text { 向はあり）. }\end{array}$ \\
\hline Savitz et al. ${ }^{14)}$ & 2019 & $29 / 19$ & 動注 & $\begin{array}{l}\text { 自家骨䯣由来細胞 } \\
\text { (ALD-401) }\end{array}$ & $\begin{array}{l}3.08 \times 10^{6} \\
(\text { 平均值 })\end{array}$ & $13 \sim 19$ 日 & $\begin{array}{l}\text { 安全性に問題なし。 } \\
\text { 有意な機能喜全なし. }\end{array}$ \\
\hline Fang et al. ${ }^{15)}$ & 2019 & $5+5 / 6$ & 静注 & $\begin{array}{l}\text { 自家血管内皮前駆細胞 } \\
\text { もしくは䯚髄間質細胞 }\end{array}$ & $2.5 \times 10^{6} / \mathrm{kg} \times 2$ 回 & $31 \sim 37$ 日 & $\begin{array}{l}\text { 安全性に問題なし. 血管内皮前駆細胞群で } \\
\text { 副作用が少ない傾向 (プラセボと比較して). } \\
\mathrm{mRS} に \text { 差はないがSSSが3ケ月時点で改善. }\end{array}$ \\
\hline Jaillard et al. ${ }^{16)}$ & 2020 & $16 / 15$ & 静注 & 自家骨髄間葉系幹細胞 & $1 \times 10^{6} / 3 \times 10^{6}$ & 6 週以内 & $\begin{array}{l}\text { 安全性に問題なし. } \\
\text { mRS や NIHSS に差はないが, NIHSS motor } \\
\text { score や Fugl-Meyer motor score 等に差あり. }\end{array}$ \\
\hline
\end{tabular}

略語：mRS, modified Rankin Scale; NIHSS, National Institute of the Health Stroke Scale; SSS, Scandinavia Stroke Scale.

表 2 本邦で進行中の脳梗塞に対する幹細胞治療治験

\begin{tabular}{|c|c|c|c|c|c|c|}
\hline フェーズ & 製品名 & 使用細胞 & 投与経路 & 治療時期 & デザイン & 実施施設 \\
\hline 3 & STR01 & 自家骨髄間葉系幹細胞 & 静注 & 74 日以内 & プラセボ対照二重盲検ランダム化 & 札幌医科大学 \\
\hline 1 & HUNS001-01 & 自家骨髄間質細胞 & 脳内 & 74 日以内 & オープンラベル, 用量対照 & 北海道大学 \\
\hline 2 & CL2020 & 他家 Muse 細胞製品 & 静注 & $14 \sim 28$ 日 & プラセボ対照二重盲検ランダム化 & 東北大学 \\
\hline $2 / 3$ & Multistem/HLCM051 & 他家間葉系幹細胞 & 静注 & $18 \sim 36$ 時間 & プラセボ対照二重盲検ランダム化 & 多施設 \\
\hline $1 / 2$ & JTR-161 & 他家歯髄幹細胞 & 静注 & 48 時間以内 & プラセボ対照二重盲検ランダム化 & 多施設 \\
\hline
\end{tabular}

肧性幹 (embryonic stem: ES) 細胞, 人工多能性幹細 胞 (induced pluripotent stem: iPS) 細胞, iSC (ischemiainduced multipotent stem cell) ${ }^{17}$ ), Muse (multilineagedifferentiating stress enduring) 細胞 ${ }^{18,19)}$ ，など，枚挙 に遑がない，各々には特徴があるため，治療しよう とする疾患やその時期に合わせて有利な細胞を選択 すればよいと考えられる。我々の研究グループでは Muse 細胞を用いた脳梗塞治療の研究に取り組んで きた.

Muse 細胞は，骨髄から末梢血に動員され，あらゆ る臓器の結合組織に分布し, 様々な組織に分化する 新たな多能性幹細胞である ${ }^{18,19)}$ 。糖鎖である SSEA (stage specific embryonic antigen)-3 を表面抗原として
分離回収できる ${ }^{18-20)}$. Muse 細胞は浮遊培養下で自 己複製能を持ち, ES 細胞の肧葉体と類似したクラス ターを形成し，それらは Oct3/4 (octamer-binding transcription factor $3 / 4$ ), Sox2 (sex determining region Y-box 2), Nanog (homeobox protein NANOG) など の多能性幹細胞マーカーを発現している ${ }^{18)}$.また, それらのクラスターを接着培養すると, 分化誘導す ることなく外胚葉系, 中胚葉系, 内胚葉系のいずれ の細胞にも分化する多能性を有する ${ }^{18)}$. さらに, Muse 細胞は腫瘍形成の可能性が低い間葉系幹細胞 中に存在しているため, Muse 細胞自体も腫瘍形成の 可能性が低い細胞であることが示唆される ${ }^{20)}$.

Muse 細胞を治療に用いる際には目的とする細胞に 


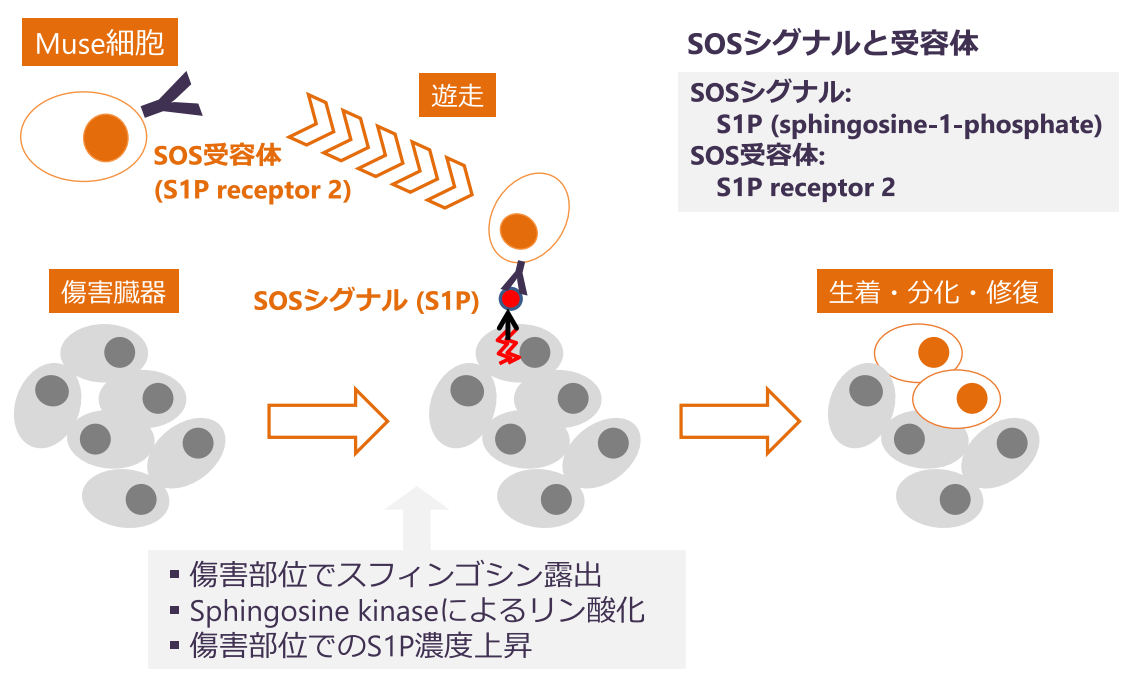

図 1 Muse 細胞遊走のメカニズム. 臟器が傷害されると破綻した細胞膜においてスフィンゴシンが露出し, 次いで sphingosine kinaseによりリン酸化され S1P に変化し，S1P 局所濃度が増加する. Muse 細胞はS1P receptor 2 を有するため, これ を用いて傷害局所に遊走することが知られており，病変部位に到達後に自発的に分化・修復すると考えられている。

分化誘導する必要がなく，そのまま静脈内に投与す るだけで傷害部位に遊走, 集積し, その場に必要と される細胞に自発的に分化することで, 組織を修復 するという特徵を有する。S1P（ Sphingosine-1Phosphate ; スフィンゴシン 1 リン酸) - S1P 受容体 2 （S1PR2）を介したメカニズムにより Muse 細胞は傷 害組織に到達することが明らかになった ${ }^{21-23)}$. 細胞 が損傷を受けると, 細胞膜の構成要素として存在す るスフィンゴシンが細胞質に存在する酵素と反応す ることによって S1Pが生成され，それが急性期の炎 症やダメージのシグナルとなる. Muse 細胞は S1PR2 を有しているため, S1Pが豊富な組織を認識して遊 走する ${ }^{23)}$ (図 1)。さらに, 遊走した Muse 細胞は自 発的に様々な細胞への分化を示す ${ }^{22-34)}$ (図 1). 例え ば脳梗塞 ${ }^{24-26)}$ や新生児低酸素性虚血性脳症 ${ }^{27)}$ では 神経細胞や乏突起膠細胞に分化し, 心筋梗塞では心 筋細胞 ${ }^{22,23)}$, 表皮水疮症では角化細胞, 毛包細胞, 血管内皮細胞, 皮脂腺細胞などの皮膚構成要素に分 化した ${ }^{28)}$. 肝障害では肝細胞, 胆管細胞, 類洞細胞 29,30), 腎不全では蛸足細胞, メサンギウム細胞や内 皮細胞などの糸球体を構成する細胞 ${ }^{31)}$, 大動脈瘤で は血管内皮細胞と平滑筋細胞 ${ }^{32)}$, 脊髄損傷では神経 細胞 ${ }^{33)}$, 筋萎縮性側索硬化症では星状膠細胞 ${ }^{34)}$ な どへの分化が確認され, Muse 細胞, あるいは Muse
細胞製品 CL2020 が傷害に応じて必要な細胞に分化 することが報告されている。このように高い安全性 と多能性を有し, 傷害組織に遊走し修復する Muse 細胞は, 有力な細胞治療のソースと考えられる.

\section{Muse 細胞による脳梗塞治療}

我々は, 最も沉用されるラット中大脳動脈閉塞／ 再開通モデルの急性期に Muse 細胞を局所投与する ところから実験を開始した. Muse 細胞は投与後 84 日の段階で生着しており, 神経細胞およびそ突起膠 細胞に分化することにより神経回路網を再建し, 運 動および感覚機能を改善した ${ }^{24)}$.さらにマウスラク ナ梗塞モデルに対して亜急性期に Muse 細胞を局所 投与することにより運動機能が回復すること, 移植 された Muse 細胞から軸索が伸長し, 反対側の頸髄 にまで到達しうることも報告した ${ }^{25)}$ 。この段階で, 図 1 に示したように, Muse 細胞がS1P-S1PR2の機構 を用いて傷害部位に遊走することも明らになってい たため, 静脈内投与を優先する方針に転換した。臨 床を見据えた Muse 細胞製品 CL2020 が開発されたこ とも受け, さらにマウスラクナ梗塞モデル（図 2A） の亜急性期ならびに慢性期にCL2020を投与した。 CL2020 投与により, 脳梗塞により悪化していた運動 


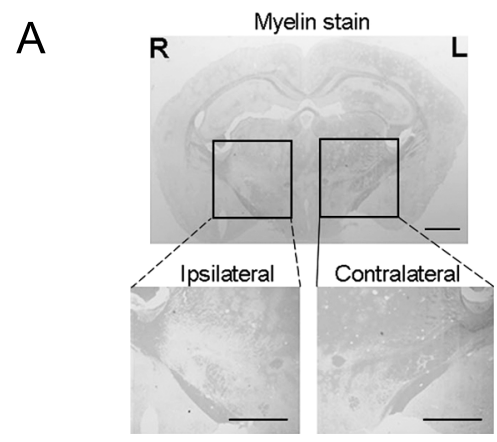

B

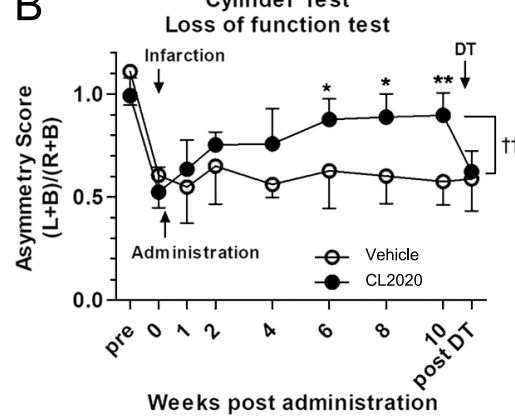

C $2 \mathrm{~mm}$ posterior
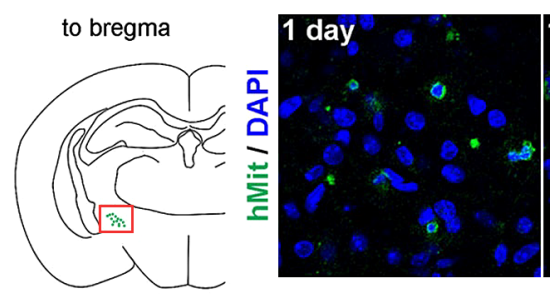

D
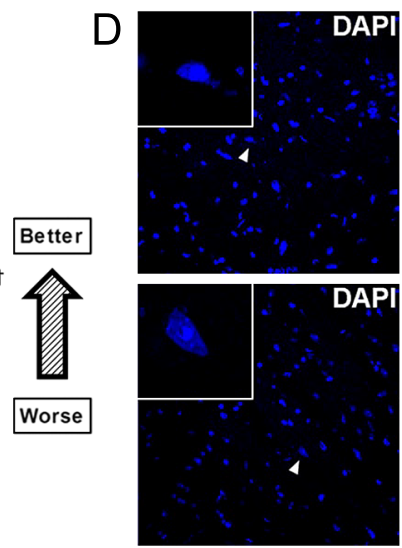
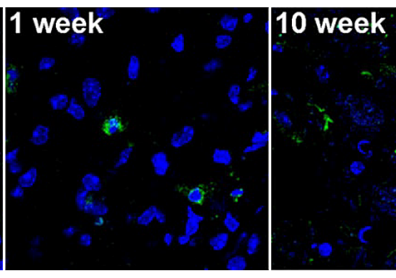

10 week

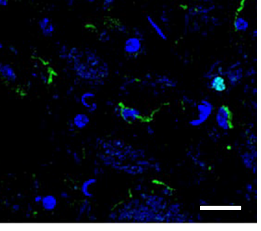

-
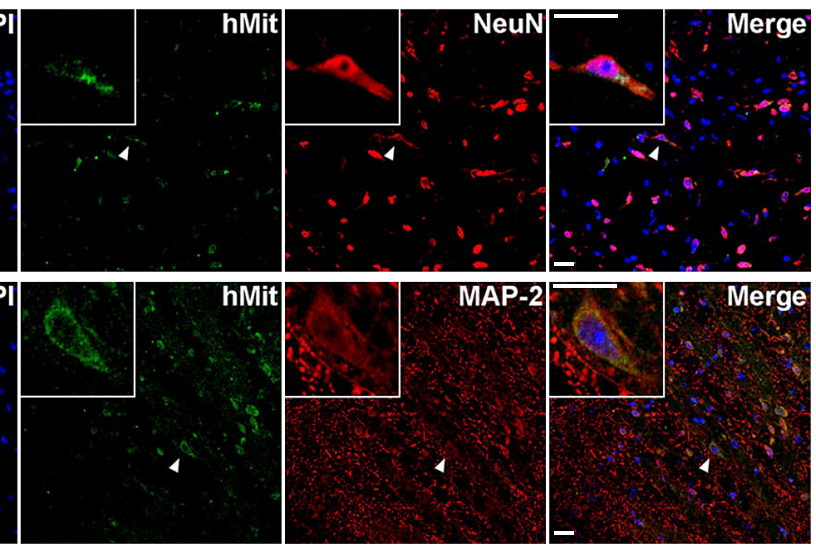

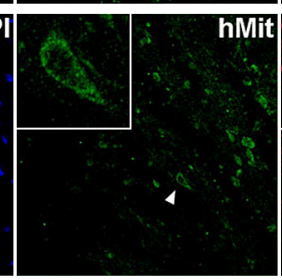

図 2 西急性期ラクナ梗塞に対する Muse 細胞製品 CL2020 の治療効果. A, ラクナ梗塞モデル. Bregma から 2 mm 後方の スライスのミエリン染色では，内方後脚近傍のミエリン脱落が確認できる．スケールバーは $1,000 \mu \mathrm{m} . \mathrm{B}$, ジフテリ ア毒素を用いた機能亯失試験. マウスにラクナ梗塞を誘導し，9 日後にCL2020 を静脈内投与した. 投与 6〜10週後 に有意な運動機能改善（Asymmetryスコア上昇）を認めた. 少量のジフテリア毒素（DT）を腹腔内投与すると，改 善していた運動機能が, 非細胞治療群（Vehicle 群）と同程度にまで再増悪した. * $\mathrm{p}<0.05, * * \mathrm{p}<0.01, \dagger \dagger \mathrm{p}<$ 0.01. C, 覀急性期ラクナ梗塞にCL2020 を投与後の蛍光免疫染色. 赤色の四角は, 投与後 10 週の時点で主にヒトミ トコンドリア陽性細胞が分布する領域を表し, その分布を緑色の点で示した. 1 日, 1 週, 10 週いずれに時点でもヒ トミトコンドリア陽性細胞が生着していることが分かる．スケールバーは $20 \mu \mathrm{m} . \mathrm{D}$ ，蛍光免疫三重染色．CL2020 投与後 10 週の時点でDAPI（4',6-diamidino-2-phenylindole；核染色）, hMit（ヒトミトコンドリア）と NeuN（neuronal nuclei）/MAP-2 （microtubule-associated protein-2）（いずれも神経細胞のマーカー）を用いて染色した. ラクナ梗塞後 にヒトミトコンドリア陽性細胞は神経細胞マーカーである NeuN/MAP-2 陽性細胞と共在していることが分かる。 ス

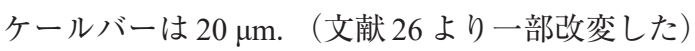

機能が有意に改善し（四 2B），ジフテリア毒素を用 いてマウスに移植されたヒト由来細胞を選択的に排 除すると, 運動機能が再度増悪した（図 2B）. CL2020 は梗塞巣周囲に生着し神経細胞に分化していた（図 2C，D）。これらにより，CL2020は神経回路に組み 込まれ，運動機能を改善することが示唆された。

前臨床試験を経て，2018 年に我々は业急性期脳梗 塞を対象とした二重盲検プラセボ対照の第二相治験 を開始した（JapicCTI-184103，脳梗塞患者を対象と したCL2020の臨床試験)，本稿執筆時点では治験継 続中である.

\section{6. 他臓器の Muse 細胞による治験}

Muse 細胞は脳梗塞のみならず, 様々な蔵器での臨 床応用も進んでいる。 2021 年 3 月の段階で, 心筋梗 塞, 表皮水疮症, 脊髄損傷, 新生児低酸素性虚血性 脳症, 筋萎縮性側索硬化症に対する治験が行われて いる。脳梗塞のみならず，様々な疾患に対する新規 治療法として確立することを期待したい.

\section{7. 結語}

脳梗塞に対する幹細胞治療の現状を概説後に, Muse 細胞の特徵を説明し，さらには我々の Museを 
用いた神経再生医療に対する取り組みを述べた。 Muse 細胞は安全性と有効性を両立する有力な細胞 ソースであり，既存の治療とは一線を画するような 大きな治療効果も期待される. 幹細胞治療は未だ発 展途上であるが，今後様々な細胞による治療が実用 化し, 脳梗塞患者に福音がもたらされることを心よ り期待する.

著者全員の利益相反（COI）の開示： 新妻邦泰：臨床研究 (治験) (生命科学インスティ テュート), 研究費 (共同研究, 寄付金等)（生命科 学インスティテュート)

冨永悌二：研究費（共同研究, 寄付金等）（生命科学 インスティテュート)

\section{文献}

1) Ramón y Cajal S: Degeneration and regeneration of the nervous system (Translated by RM Day from the 1913 Spanish edition). Oxford: Oxford University Press, 1928.

2) Jin K, Minami M, Lan JQ, Mao XO, Batteur S, Simon RP, Greenberg DA: Neurogenesis in dentate subgranular zone and rostral subventricular zone after focal cerebral ischemia in the rat. Proc Natl Acad Sci U S A 98: 4710-4715, 2001.

3) Jin $K$, Wang X, Xie L, Mao XO, Zhu W, Wang Y, Shen J, Mao Y, Banwait S, Greenberg DA: Evidence for strokeinduced neurogenesis in the human brain. Proc Natl Acad Sci U S A 103: 13198-13202, 2006.

4) Bang OY, Kim EH, Cha JM, Moon GJ: Adult stem cell therapy for stroke: Challenges and progress. J Stroke 18: 256266, 2016.

5) Marei HE, Hasan A, Rizzi R, Althani A, Afifi N, Cenciarelli C, Caceci T, Shuaib A: Potential of stem cell-based therapy for ischemic stroke. Front Neurol 9: 34, 2018.

6) Janowski M, Wagner DC, Boltze J: Stem cell-based tissue replacement after stroke: Factual necessity or notorious fiction? Stroke 46: 2354-2363, 2015.

7) Kondziolka D, Steinberg GK, Wechsler L, Meltzer CC, Elder E, Gebel J, Decesare S, Jovin T, Zafonte R, Lebowitz J, Flickinger JC, Tong D, Marks MP, Jamieson C, Luu D, BellStephens T, Teraoka J: Neurotransplantation for patients with subcortical motor stroke: A phase 2 randomized trial. J Neurosurg 103: 38-45, 2005.

8) Savitz SI, Dinsmore J, Wu J, Henderson GV, Stieg P, Caplan LR: Neurotransplantation of fetal porcine cells in patients with basal ganglia infarcts: A preliminary safety and feasibility study. Cerebrovasc Dis 20: 101-107, 2005.

9) Bang OY, Lee JS, Lee PH, Lee G: Autologous mesenchymal stem cell transplantation in stroke patients. Ann Neurol 57: 874882, 2005.

10) Chen DC, Lin SZ, Fan JR, Lin CH, Lee W, Lin CC, Liu YJ, Tsai CH, Chen JC, Cho DY, Lee CC, Shyu WC: Intracerebral implantation of autologous peripheral blood stem cells in stroke patients: A randomized phase II study. Cell Transplant 23: 1599-1612, 2014.

11) Prasad K, Sharma A, Garg A, Mohanty S, Bhatnagar S, Johri S, Singh KK, Nair V, Sarkar RS, Gorthi SP, Hassan KM, Prabhakar S, Marwaha N, Khandelwal N, Misra UK, Kalita J, Nityanand S; InveST Study-Group: Intravenous autologous bone marrow mononuclear stem cell therapy for ischemic stroke: A multicentric, randomized trial. Stroke 45: 3618 3624, 2014.

12) Hess DC, Wechsler LR, Clark WM, Savitz SI, Ford GA, Chiu D, Yavagal DR, Uchino K, Liebeskind DS, Auchus AP, Sen S, Sila CA, Vest JD, Mays RW: Safety and efficacy of multipotent adult progenitor cells in acute ischaemic stroke (MASTERS): A randomised, double-blind, placebocontrolled, phase 2 trial. Lancet Neurol 16: 360-368, 2017.

13) Bhatia V, Gupta V, Khurana D, Sharma RR, Khandelwal N: Randomized assessment of the safety and efficacy of intraarterial infusion of autologous stem cells in subacute ischemic stroke. AJNR Am J Neuroradiol 39: 899-904, 2018.

14) Savitz SI, Yavagal D, Rappard G, Likosky W, Rutledge N, Graffagnino C, Alderazi Y, Elder JA, Chen PR, Budzik RF Jr, Tarrel R, Huang DY, Hinson JM Jr: A phase 2 randomized, sham-controlled trial of internal carotid artery infusion of autologous bone marrow-derived ALD-401 cells in patients with recent stable ischemic stroke (RECOVER-Stroke). Circulation 139: 192-205, 2019.

15) Fang J, Guo Y, Tan S, Li Z, Xie H, Chen P, Wang K, He Z, He $\mathrm{P}$, Ke Y, Jiang X, Chen Z: Autologous endothelial progenitor cells transplantation for acute ischemic stroke: A 4-year follow-up study. Stem Cells Transl Med 8: 14-21, 2019.

16) Jaillard A, Hommel M, Moisan A, Zeffiro TA, Favre-Wiki IM, Barbieux-Guillot M, Vadot W, Marcel S, Lamalle L, Grand S, Detante O; (for the ISIS-HERMES Study Group): Autologous mesenchymal stem cells improve motor recovery in subacute ischemic stroke: A randomized clinical trial. Transl Stroke Res 11: 910-923, 2020.

17) Tatebayashi K, Tanaka Y, Nakano-Doi A, Sakuma R, Kamachi S, Shirakawa M, Uchida K, Kageyama H, Takagi T, Yoshimura S, Matsuyama T, Nakagomi T: Identification of multipotent stem cells in human brain tissue following stroke. Stem Cells Dev 26: 787-797, 2017.

18) Kuroda $Y$, Kitada M, Wakao S, Nishikawa K, Tanimura $Y$, Makinoshima H, Goda M, Akashi H, Inutsuka A, Niwa A, Shigemoto T, Nabeshima Y, Nakahata T, Nabeshima Y, Fujiyoshi Y, Dezawa M: Unique multipotent cells in adult human mesenchymal cell populations. Proc Natl Acad Sci U S A 107: 8639-8643, 2010.

19) Kuroda Y, Wakao S, Kitada M, Murakami T, Nojima M, Dezawa M: Isolation, culture and evaluation of multilineagedifferentiating stress-enduring (muse) cells. Nat Protoc 8: 1391-1415, 2013.

20) Wakao S, Kitada M, Kuroda $Y$, Shigemoto $T$, Matsuse D, Akashi H, Tanimura Y, Tsuchiyama K, Kikuchi T, Goda M, Nakahata T, Fujiyoshi Y, Dezawa M: Multilineagedifferentiating stress-enduring (muse) cells are a primary source of induced pluripotent stem cells in human fibroblasts. Proc Natl Acad Sci U S A 108: 9875-9880, 2011.

21) Hori E, Hayakawa Y, Hayashi T, Hori S, Okamoto S, Shibata T, Kubo M, Horie Y, Sasahara M, Kuroda S: Mobilization of 
pluripotent multilineage-differentiating stress-enduring cells in ischemic stroke. J Stroke Cerebrovasc Dis 25: 1473-1481, 2016.

22) Tanaka T, Nishigaki K, Minatoguchi S, Nawa T, Yamada $Y$, Kanamori H, Mikami A, Ushikoshi H, Kawasaki M, Dezawa M, Minatoguchi S: Mobilized muse cells after acute myocardial infarction predict cardiac function and remodeling in the chronic phase. Circ J 82: 561-571, 2018.

23) Yamada Y, Wakao S, Kushida Y, Minatoguchi S, Mikami A, Higashi K, Baba S, Shigemoto T, Kuroda Y, Kanamori H, Amin M, Kawasaki M, Nishigaki K, Taoka M, Isobe T, Muramatsu C, Dezawa M, Minatoguchi S: S1P-S1PR2 axis mediates homing of muse cells into damaged heart for longlasting tissue repair and functional recovery after acute myocardial infarction. Circ Res 122: 1069-1083, 2018.

24) Uchida H, Morita T, Niizuma K, Kushida Y, Kuroda Y, Wakao S, Sakata H, Matsuzaka Y, Mushiake H, Tominaga T, Borlongan $\mathrm{CV}$, Dezawa $\mathrm{M}$ : Transplantation of unique subpopulation of fibroblasts, muse cells, ameliorates experimental stroke possibly via robust neuronal differentiation. Stem Cells 34: 160-173, 2016.

25) Uchida H, Niizuma K, Kushida $Y$, Wakao S, Tominaga T, Borlongan CV, Dezawa M: Human muse cells reconstruct neuronal circuitry in subacute lacunar stroke model. Stroke 48: 428-435, 2017.

26) Abe T, Aburakawa D, Niizuma K, Iwabuchi N, Kajitani T, Wakao S, Kushida Y, Dezawa M, Borlongan CV, Tominaga T: intravenously transplanted human multilineage-differentiating stress-enduring cells afford brain repair in a mouse lacunar stroke model. Stroke 51: 601-611, 2020.

27) Suzuki T, Sato Y, Kushida Y, Tsuji M, Wakao S, Ueda K, Imai K, Iitani Y, Shimizu S, Hida H, Temma T, Saito S, Iida H, Mizuno M, Takahashi Y, Dezawa M, Borlongan CV, Hayakawa M: Intravenously delivered multilineagedifferentiating stress enduring cells dampen excessive glutamate metabolism and microglial activation in experimental perinatal hypoxic ischemic encephalopathy. J Cereb Blood Flow Metab, 2020 [Online ahead of print], doi: 10.1177/0271678X20972656.
28) Fujita Y, Komatsu M, Lee SE, Kushida Y, NakayamaNishimura C, Matsumura W, Takashima S, Shinkuma S, Nomura T, Masutomi N, Kawamura M, Dezawa M, Shimizu $\mathrm{H}$ : Intravenous injection of muse cells as a potential therapeutic approach for epidermolysis bullosa. J Invest Dermatol 141: 198-202.e6, 2021.

29) Katagiri H, Kushida Y, Nojima M, Kuroda Y, Wakao S, Ishida K, Endo F, Kume K, Takahara T, Nitta H, Tsuda H, Dezawa M, Nishizuka S: A distinct subpopulation of bone marrow mesenchymal stem cells, muse cells, directly commit to the replacement of liver components. Am J Transplant 16: 468483, 2016.

30) Iseki M, Kushida Y, Wakao S, Akimoto T, Mizuma M, Motoi F, Asada R, Shimizu S, Unno M, Chazenbalk G, Dezawa M: Muse cells, nontumorigenic pluripotent-like stem cells, have liver regeneration capacity through specific homing and cell replacement in a mouse model of liver fibrosis. Cell Transplant 26: 821-840, 2017.

31) Uchida N, Kushida Y, Kitada M, Wakao S, Kumagai N, Kuroda Y, Kondo Y, Hirohara Y, Kure S, Chazenbalk G, Dezawa M: Beneficial effects of systemically administered human muse cells in adriamycin nephropathy. J Am Soc Nephrol 28: 2946-2960, 2017.

32) Hosoyama K, Wakao S, Kushida Y, Ogura F, Maeda K, Adachi O, Kawamoto S, Dezawa M, Saiki Y: Intravenously injected human multilineage-differentiating stress-enduring cells selectively engraft into mouse aortic aneurysms and attenuate dilatation by differentiating into multiple cell types. J Thorac Cardiovasc Surg 155: 2301-2313.e4, 2018.

33) Kajitani $T$, Endo $T$, Iwabuchi $N$, Inoue $T$, Takahashi $Y$, Abe $T$, Niizuma K, Tominaga $\mathrm{T}$ : Association of intravenous administration of human Muse cells with deficit amelioration in a rat model of spinal cord injury. J Neurosurg Spine 1: 1-8, 2021.

34) Yamashita T, Kushida Y, Wakao S, Tadokoro K, Nomura E, Omote Y, Takemoto M, Hishikawa N, Ohta Y, Dezawa M, Abe K: Therapeutic benefit of Muse cells in a mouse model of amyotrophic lateral sclerosis. Sci Rep 10: 17102, 2020. 